\title{
Tropical deforestation: Can property rights stem the tide?
}

\section{Daniel Bayley, Kristen Mabee, Shane Sidsworth, Niamh Wall, Kassandra Wallace, Yanfeng Wang}

Department of Food, Agricultural and Resource Economics, University of Guelph, Guelph, ON Canada. Faculty supervisor: Dr. Glen Fox For correspondence, please email: dbayley@alumni.uoguelph.ca.

\section{Abstract}

In this report, the property right structures surrounding tropical forest management are analyzed with a specific case study presented on tropical forests in Honduras. In order to adequately understand the set of property rights in place surrounding tropical forests, the applicable sets of property rights are laid out and explained (private, common, state, and open access). It is argued that the current property rights regimes in place surrounding tropical forests are inadequate and are the issue leading to high levels of deforestation. Conflicts and controversies surrounding the issue are presented for a counterargument and separate view of the issue. It was found that the current property rights regime in Honduras is inadequate for effective resource management as it lacks enforceability along with structure, and is the prominent issue surrounding tropical deforestation. Private property rights were the most effective form of property rights found for maintaining natural resources and it is therefore recommended that private ownership be instilled upon tropical forests to reduce the rate of deforestation. Free Market Environmentalism (FME) is offered as a solution to the current methodology for the management of tropical forests, as it advocates for private ownership and an enforceable set of rights. Therefore, it is recommended that a private property rights regime following the FME methodology replace existing state property rights in order to stem the tide of tropical deforestation.

\section{Introduction}

According to Mendelsohn (1994), the fact that tropical forests are shrinking is unmistakable. Mendelsohn (1994) also claims that since the post-World War II development boom the rate of tropical deforestation is at an all-time high, and there is no evidence of it being utilized efficiently. Sandler (1993) predicted that if the rate of tropical deforestation were to continue, the tropical forests would virtually disappear in just over 50 years. The importance of these ecosystems is stressed by O'Conner (2008) in his paper "Governing the Global Commons: Linking carbon sequestration and biodiversity conservation in tropical forests." O'Conner (2008) points out that these environments are vital to mitigating climate change through carbon sequestration, and that deforestation and forest degradation represent a major source of greenhouse gas emissions. These forests are abundantly rich in biodiversity and habitat, giving them scientific and medicinal purposes (Sandler, 1993). For example, Sandler (1993) deduces that one quarter of all prescription drugs sold in the United States are derived from tropical plants and that the biodiversity provides genetic material useful for genetic engineering. There are many reasons why the tropical forests need to be maintained and conserved for their continued use, however, it is not this paper's intent that the resource goes unused. It is more-so the view of Sandler's 1993 paper in that tropical forests should be utilized at an efficient and sustainable level, to maintain continued use for future generations. Many analyses and papers have attempted to summarise and locate the underlying issues surrounding the resources inefficient consumption (Mendelsohn 1994; Amacher et al. 2009; Lopez et al. 2010). Some of the reoccurring themes in these studies include: illegal logging, expropriation rights, immigration or population expansion and encroachment, and improved access to otherwise inaccessible tracts of forest (Mendelsohn 1994; Amacher et al. 2009; Lopez et al. 2010)These recurring themes, and others, are a blend of systemic problems that take root in a more underlying matter of poorly defined and insecure property rights. Thus, the purpose of this paper is to identify how current property structures have failed to preserve tropical forests and to illustrate how the implementation of a well-defined property right system could result in reduced deforestation activity. Four specific types of property rights structures (open access, state, communal, and private) are outlined and explained to better understand the economy surrounding tropical forests. 
To better analyze tropical deforestation in a more targeted manner, a case study focusing on the use of tropical forest resources in Honduras will be employed in this analysis. The trends in the use of the resource will be examined in the context of the changing property rights regimes and the impact this has on the allocation of resources. A Free Market Environmentalist (FME) approach is suggested as a remedy for currently insecure property rights in areas such as Honduras, as it is found that the FME perspective aligns with the recommended solution of an enforced private property rights regime. It is argued that the underlying cause for the inefficient use of tropical forest ecosystems is the poorly defined, and therefore insecure, property rights with a discussion on a potential solution.

\section{Institutions and Policy}

In order to understand the obstacles preventing Honduras from reaching its economic potential, it is important to understand the current economy that exists in the region. Nelson (2003) outlines the property rights structures in this area as open access, state, common, and private. All four property rights structures are active in Honduras; however the lack of enforcement of these rights typically leads to an open access situation (Hyde et al, 1996). Nelson (2003) also includes reformed ownership as a type of property right regime, existing where parcels of land have been distributed to individuals through "agrarian reform legislation" developed throughout the 1960s and 1970s. Under this type of ownership, residents hold legal title to their land.

\section{Open Access}

Hyde et al. (1996) states that open access occurs when there are no property rights, or when existing property rights are not enforced. Conditions such as this lead to high deforestation rates, due to a lack of incentive for conservation (Nelson, 2003). Hyde et al (1996) also states that conservation can only occur if the cost of extraction in an open access situation is greater than the benefits received. De Alessi (2002) goes on to explain that tragedy of the commons arises with open access resources, as without exclusion rights, users will use a resource until the point of depletion, simply so one party can attain the benefits before another party. Additionally, Araujo et al. (2008) states that without legal institutions, there are no incentives for accumulation of long term assets, meaning the resource will be consumed with no plan for its future re-accumulation.

Figure 1 illustrates the issue and solution to open access resources. Tietenberg and Lewis (2009) provide rationale to these situations. The goal when harvesting is to maximize present value of net benefits (marginal revenue is equal to marginal cost). In an open access condition, this occurs at the efficient level, $\mathrm{Q}^{*}$. At this point the resource population is greater than at the equilibrium level, Q1 (maximum sustainable yield), where marginal costs are zero.

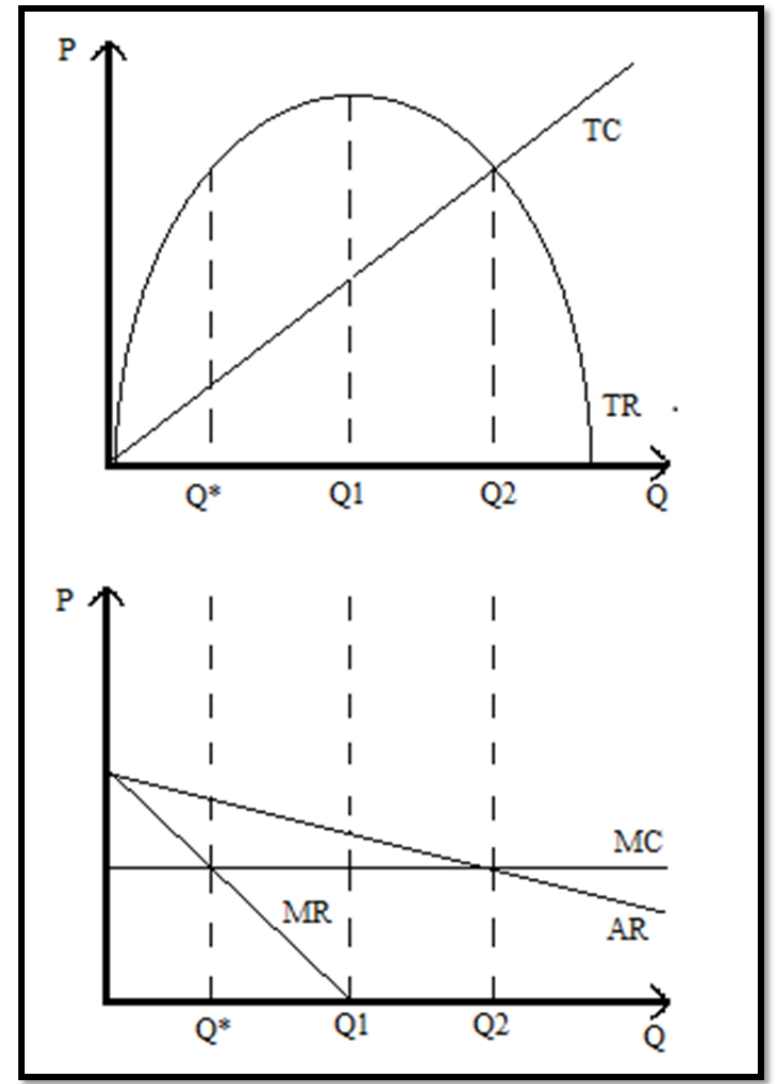

Figure 1. Diagram of Total Cost (TC) and Total Revenue (TR) versus Marginal Revenue (MR), Marginal cost (MC), and Average Revenue (AR) to determine the efficient allocation of resources under an open access property rights regime. The efficient allocation of resources is found at $Q^{*}$ where Marginal Revenue is equivalent to Marginal Cost. Source: Tietenberg, T. and L. Lewis, 2009.

Scarcity rent arises when harvesting efforts move beyond the maximum sustainable yield; harvesting one more unit will cause intergenerational external cost. Increased harvesting today decreases future resource population, leaving future generations with lower profits. This occurs at the effort level, Q2 (average revenue is equal to average costs), when overharvesting prevents regrowth in a population (Tietenberg and Lewis, 2009).

Tietenberg and Lewis (2009) continue explaining Figure 1 by saying that when resources have one owner, $Q^{*}$ would be reached, due to maximizing profit incentives by conserving resources. In a case where there are multiple users who agree upon and enforce the usage of the resource, it becomes a common property right (explained further on). However, multiple users lacking an agreement between them have no incentives to conserve, and therefore will harvest until profits are equal to zero, Q2 (total revenue is equal to total costs). As the demand for the resource increases, efforts expand and the resource population decreases, this results in the value of the resource increasing. With no restriction, control, and exclusion, over-depletion occurs due to lack of incentive to conserve. Individuals want to maximize their 
harvest, for if they conserve, another user will benefit from and consume the resource first. This is the cause of inefficient allocation. A contemporaneous external cost arises when too much effort is required from current harvesters, leaving them with reduced returns. When this is combined across multiple users, it leads to multiple proprietors rapidly mining the resource to the point where it becomes inefficient to continue, or the resource is fully depleted (Tietenberg and Lewis, 2009). This information indicates that an open access set of rights could lead to complete tropical forest resource depletion, and therefore is not recommended as a forest management system.

\section{State Property Rights}

According to Wong (2004), state ownership implies that the government has complete regime entitlement to the resource, meaning it has full ability to control, access, and regulate the resource. Wong (2004) and Bromley (2003) argue that governments tend to fail in managing natural resources under state property regimes. These regimes are more likely to transform into open access regimes due to the lack of effective management and enforcement.

The Nanjundaiah case study (2008) is an example of failure in state property rights. Nagarahole National Park in India is owned and controlled by the state (Nanjundaiah, 2008). Under this regime, Nanjundaiah (2008) found that important pressures on the park area are present and identifies them as: frequent forest fires, illegal poaching, and logging by timber mafia. Nanjundaiah (2008) indicates that a state property rights regime has not been effective in managing the forest area and biodiversity in the Nagarahole National Park, due to the aforementioned pressures.

\section{Common Property Rights}

Wong (2004) states that under a common property regime, the resource is held by an identifiable group of users who can exclude others and regulate the use of the resource. Examples of these groups include: tribal groups, villages, and extended families. Common property is similar to private property in the rights of ownership; however the ownership is spread out among a community of users, as opposed to an individual. Each user will have specific rights to the land as set out by the group, in which case it is up to the group to decide how the land is used. Southgate (2002) states that this causes higher transaction costs than that of private ownership. In this situation, there is also incentive to maintain the land in order to maximize future net benefits for the entire group or community (Wong, 2004).

\section{Private Property Rights}

Wong (2004) explains that private property allows an individual the right to exclude others and to regulate the use of their resources. Under this regime, Berkes (1996), Wong (2004) and Bromley (2003) claim that it provides institutional arrangement for successful exclusion as this type of property is more effective in encouraging the government to enforce their rights. They state that private property rights appear to be stable and adaptive because of the social and legal sanction, which are able to exclude excess population through the power of the state.

According to experiments conducted by Tucker (1999) in La Campa of Honduras, private forest owners were expected to have a lower discount rate, so they tend to place importance on the future value of the resource. Therefore, Tucker (1999) concluded that private ownership of forested area is viewed as an optimal tenure arrangement for achieving sustainable management of natural resources.

De Soto (2000) illustrates the importance of private property rights in "The Mystery of Capital: Why Capitalism Triumphs in the West and Fails Everywhere Else." De Soto (2000) describes the extensive extralegal sector and lack of formal private property rights as a bell jar. Most people living in developing countries are described as living "outside the bell jar," where property is used and protected by extralegal arrangements rooted in informal consensus. De Soto (2000) argues the need for formal property rights in situations such as that in Honduras as this would allow voluntary market exchanges to occur, ensuring participation and the generation of a land market. Such changes can lead to reduced deforestation through imrpoved conservation and land management (explained further on).

\section{The Economic, Social and Biophysical Trends of Tropical Deforestation in Honduras}

\section{Economic Trends}

In 2013, Global Finance, a magazine focusing on global economic and financial risk, ranked 181 countries based on their estimated GDP per capita for 2013 to determine their wealth. The organization found that Honduras ranked 126th with an estimated GDP/capita of $\$ 4,741.16$ (Aridas and Pasquali, 2013). Widespread poverty in the country prevents many locals from legally purchasing residences; this classifies this population as "extra-legal." These locals reside on, and extract resources from, parcels of land which they do not legally own. In an effort to appeal to extra legals and inact a land market, as recommended by De Soto (2000), Honduras attempted a distribution of property rights in 1982 .

Nelson (2003) states that the first significant form of legislation focussing on the distribution of property rights was Decree 89 - The Land Titling Project, passed in 1982, the goal of which was to create a "viable" land market. The secure land titles granted through the Land Titling Project were thought to benefit extra-legals by (1) increasing investment in their own land, (2) allowing locals access to credit so legal ownership of land could be used as collateral against a loan, and (3) legal ownership would create a land market, as secure title of land reduces transaction costs and 
risks associated with the purchase of a parcel of land. Nelson (2003) found that the evolution from legislation primarily focusing on the inequitable distribution of land to that which grants secure legal property rights has reduced the frequency with which locals invade forests and illegally claim the land as their own.

Deterioration of the land on which an extra-legal resided was an issue prior to the Land Titling Project, as Nelson (2003) states that extra-legals did not have the financial means to "finance improvements" to the land, and they did not have the proper resources to prevent erosion, improve soil conditions, or protect the existing flora in the area. Allowing legal ownership of the land would allow landowners to gain access to loans to improve soil conditions and prevent further environmental deterioration (Nelson, 2003). Consequently this would increase yields from the existing deforested areas, reducing the requirement of new agricultural land needed to support ones family.

\section{Social Trends}

There are a number of social factors influencing the frequency and intensity of deforestation in Honduras. Godoy et al. (1997) assessed the effects of several of these factors on deforestation. The factors considered by Godoy et al. (1997) included: income, residence duration, household size, education, fallow lands, wealth, crop yield, and credit. Table 1 summarizes the findings of this study; as residence duration, household size, education, wealth, crop yield, and credit all increase, deforestation decreases. As fallow lands increase, deforestation increases. As income and age of household head increase, deforestation increases, until the factor peaks, at which point deforestation decreases. This table shows that if people are more secure with the land they control, stay on it, and put money into it, then this could result in reduced deforestation.

Table 1 - The influence of Income, Residence Duration, Household Size, Age of Household Head, Education, Fallow Lands, Wealth, Crop Yield, and Credit on forest clearing in La Campa Study area in Honduras, 1997. Source: Godoy et al, 1997. Negative relationships indicate less forest clearing as the factor increases, and positive relationships indicate greater forest clearing as the factor increases. Inverted $U$ relationships indicate forest clearing increases as the factor increases, and decreases once the factor peaks.

\begin{tabular}{|c|c|}
\hline \multicolumn{1}{|c|}{ External Factor } & $\begin{array}{c}\text { Relationship to Forest } \\
\text { Clearing } \\
\text { Income }\end{array}$ \\
\hline Residence Duration & Negative (-) \\
\hline Household Size & Negative (-) \\
\hline $\begin{array}{c}\text { Age of Household } \\
\text { Head }\end{array}$ & Inverted U \\
\hline Education & Negative (-) \\
\hline Fallow Lands & Positive (+) \\
\hline Wealth & Negative (-) \\
\hline Crop Yield & Negative (-) \\
\hline Credit & Negative (-) \\
\hline
\end{tabular}

Godoy et. al, (1997) suggest these findings be used as guidelines for local and national governments in their attempts to develop policies to deter unsustainable deforestation. The authors conclude by stating that security of property rights would aid in reducing the amount of deforestation in these areas (Godoy et al, 1997).

\section{Biophysical Trends}

Southworth and Tucker (2001) conducted a study of La Campa, Honduras that focused on the relationship between communal and private forests and the amount of deforestation and reforestation occurring under these types of ownerships. As Figure 2 shows, privately owned forests were found to have lower rates of deforestation when compared to communal forests. In the Southworth and Tucker (2001) study, reforested areas arose through the regeneration of previously logged areas, privatization of previous communal areas, and abandonment of marginal agricultural lands which allowed natural regeneration. Deforestation occurred through clearing of fallow for agricultural use and for new coffee plantations (Southworth and Tucker, 2001). Overall, the trend shown in this study area is reforestation. However, Southworth and Tucker (2001) suggest this trend is temporary as population density is expected to increase and marginal lands that were previously abandoned are expected to be inhabited. Southworth and Tucker (2001) also hypothesized that this trend results from changes in human preferences and local institutions. An example is where families move into villages to facilitate child education and well being, as opposed to remaining in isolated homesteads. This creates more pressure on forests around villages, but leaves some isolated agricultural land unattended for natural regeneration.

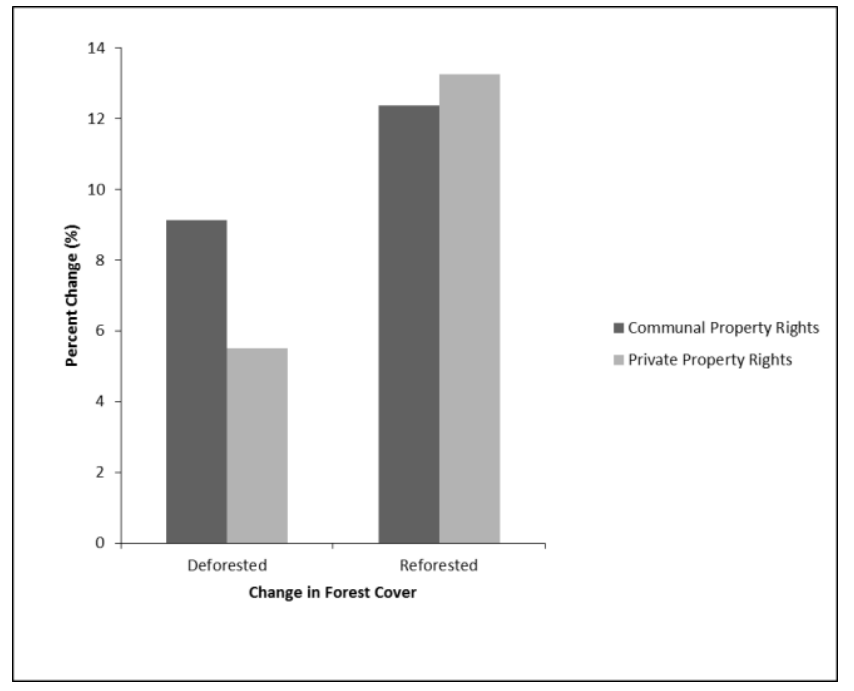

Figure 2. Percent change in forest cover under private and communal ownership systems, from 1987-1996 in Honduras. Source: Southworth \& Tucker, 2001. 
The La Campa study is a small scale example of how private and public land tenure systems impact deforestation and reforestation rates in Honduras. On a larger scale, data was collected by the Food and Agriculture Organization of the United Nations (FAO) through their 2005 and 2010 Global Forest Resources Assessments (Food and Agriculture Organization, 2005, 2010). These assessments found that the extent of forests in the area have steadily been decreasing since the 1990's, despite transitions in the forest management systems to allow greater private ownership of forests.

Tucker (1999) illustrates the change in ideologies surrounding forest management in Honduras. In 1974, the Honduran Corporation for Forestry Development was created, resulting in all trees on Honduran territory becoming state property (and therefore publicly owned) while the land on which they resided remained property of the land owner. Tucker (1999) explains that through this legislation, the public body was made responsible for all timber resources, ensuring their protection while encouraging development. This legislation also made it illegal for residents to use forest resources as timber collection for firewood, as well as prohibiting its usage for any other type of subsidence until the forests had been exploited by loggers. Tucker (1999) adds that in response to the creation of the Honduran Corporation for Forestry Development, many residents rebelled. This ultimately led to the repeal of this legislation in 1987, allowing residents to once again clear land for personal use. By 1992, the Agricultural Modernization and Development Law was created, which allowed for private ownership of forests in the area (Larmon 1999). Since the 1990 s, when $100 \%$ of tropical forests were publicly owned, increasing amounts of individual landowners have been granted private ownership of forest resources, as depicted in Figure 3. However, the majority of forests are still publicly owned (Tucker, 1999). When Figures 3 and $\mathbf{4}$ are analyzed together it reveals that the movement from public ownership to private ownership correlates with a decreasing rate of deforestation. This indicates that, although deforestation is continuing to occur, the enactment of private ownership regimes could be the cause of a reduction in deforestation rates.

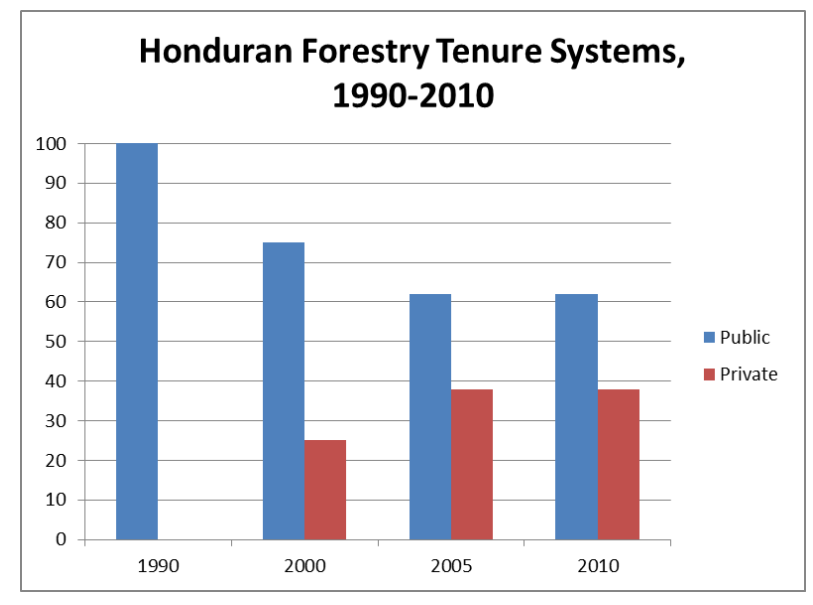

Figure 3. Comparison of ownership systems in Honduras, showing the amount of forest under each type of ownership. Source: Southworth and Tucker, 2001.

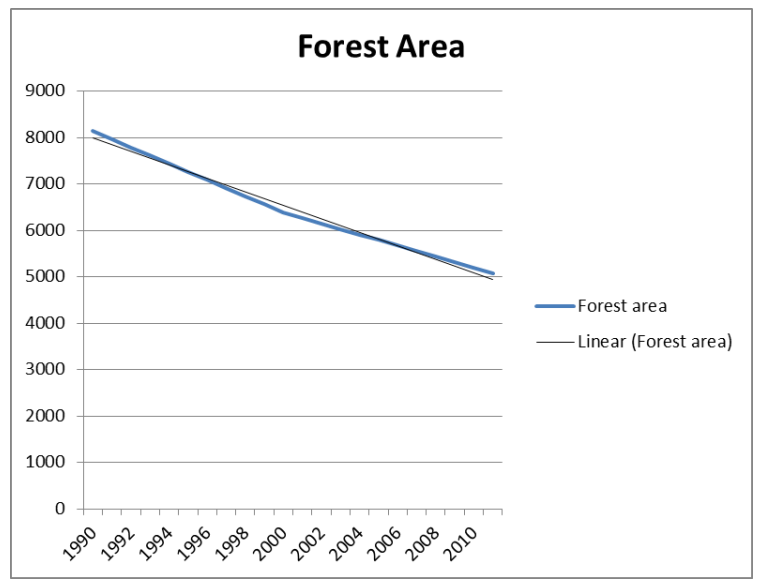

Figure 4. Extent and rate of deforestation occurring between 1990 and 2010 in Honduras. Source: Southworth and Tucker, 2001.

\section{Obstacles to Growth}

A key characteristic of common and reformed land ownership in Honduras, as explained by Nelson (2003), is the restriction in place on the purchase and sale of land under these ownerships. This restriction does not allow residents to participate in any type of land market, potentially inhibiting the growth of the local economy, and restricting extra-legals from gaining financially through exchanges of property on the legal market. Given that the formation of the legal institutions needed to ensure exclusion and clearly defined property rights require large amounts of capital to implement (Nelson, 2003), then the integration of legal property exchanges in the market could assist in providing this capital. Through legal market exchanges of property, the parties making the exchange benefit by making a desired purchase or sale, and government would benefit from tax aquired due to the sale. This additional income would make the creation of institutions required for private property regimes more attainable for Honduras.

An additional obstacle in the growth of the Honduran economy is the number of residents having no legal title to land (landless residents). Nelson (2003) shows that the number of individuals having no ownership of land is high in relation to the number of residents having ownerships of less than one hectare, 5 to 50 hectares, and greater than 50 hectares of land, as shown by Figure 5. It is observed that the number of landless residents went from 10 percent of the total population in 1952 to 27 percent of the population by 1993. A World Bank Report entitled Land Policies for Growth and Poverty Reduction (2003) states that the absence of secure property rights restricts incentives for investment into the land. As such, those residing on the land do not have an incentive to conserve that land as they fear expropriation. 


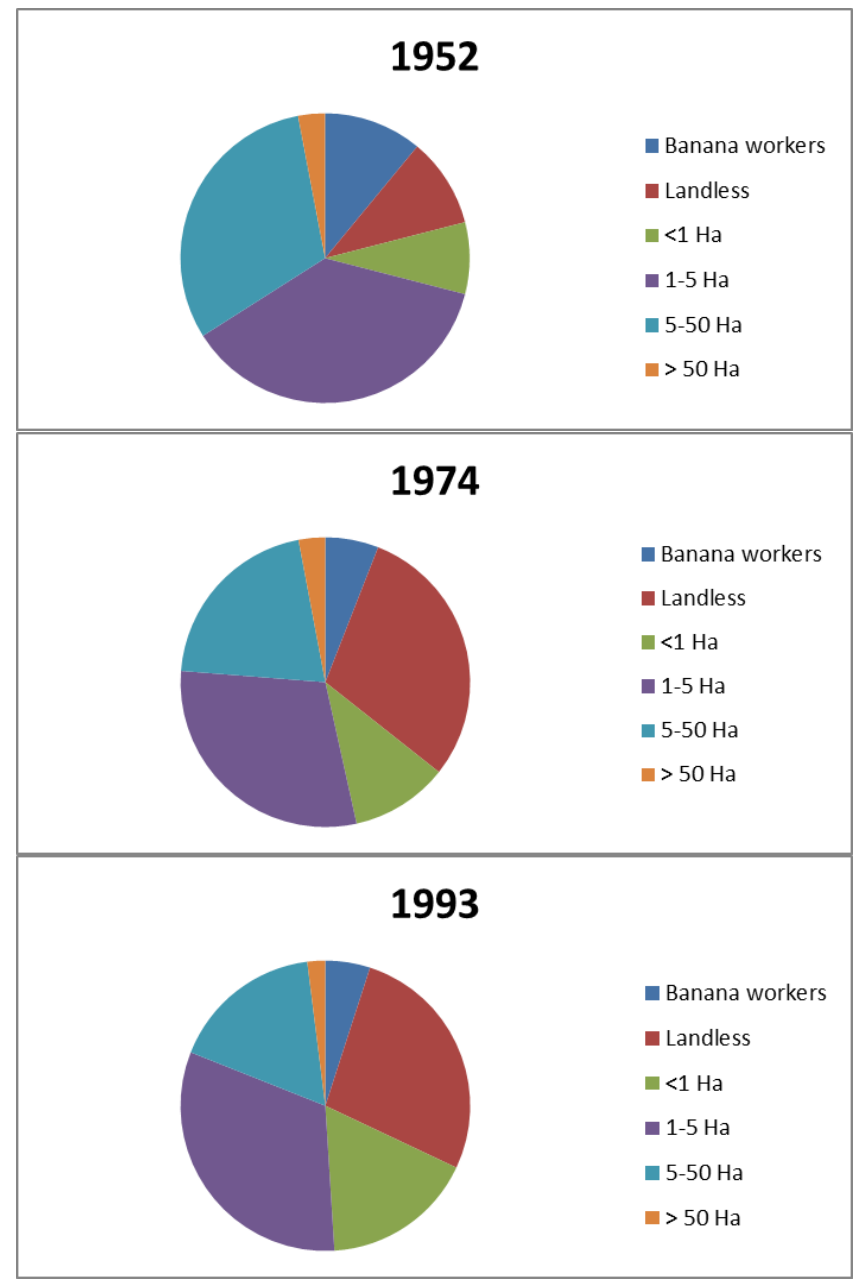

Figure 5. Percent changes in the sizes of land owned in Honduras throughout 1952, 1974 and 1993. Source: Nelson, 2003.

In order for conservation efforts to occur, property owners need to feel secure in their ownership, as it was demonstrated that secure ownership can lead to conservation (Nelson, 2003). These landless residents, an increasing portion of the population in Honduras, do not have the security and enforcement of property ownership, resulting in inefficient extraction of resources from the local tropical rainforests (Nelson, 2003).

A final hindrance in the growth of the Honduran economy as explained by Nelson (2003) is the inequitable land distribution between the poor and the "land elite." Nelsons' report shows that in 1952, 57\% of all farms belonged to farmers owning 5 hectares or less of land (smallholders), however, they controlled only $8.1 \%$ of land in agriculture. The $3 \%$ of farmers owning over 500 hectares of land (large landowners) controlled 28.3\%. A more recent census conducted in 1993 showed smallholders comprised $71.8 \%$ of all farms and controlled $13 \%$ of land in agriculture, while $1 \%$ of large landowners controlled $12.3 \%$ of the land. The unequal distribution often leads to smallholders being excluded from the land market through their lack of secure title. As described in the last paragraph, a lack of security limits collateral for loans and impedes the ability to finance improvements to land (The World Bank, 2003). As the quality of this group's land diminishes, so does the value, further reducing their capital. At the same time, large landowners can coerce the market and increase the size of their holdings. Often, large landowners can attain more land from smallholders in need of money, and can force a sale at a price substantially lower than market value. For those that do not legally own the land, it is a matter of forcing them to leave the land and claiming it. Thus, large landowners are able to control land transactions, and ultimately undermine the free functioning land market (Nelson, 2003). Without land security and a free functioning land market, Honduras is trapped in a system of inefficient land management, leading to further deforestation for inefficient agricultural practices.

Decree 89 - The Land Titling Project mentioned earlier, was the legislation focussing on the distribution of property rights in Honduras. A major difference in this legislation from previous legislations was the recognition that the underlying problem in Honduras was not the inequitable land distribution, outlined above, but the absence of legal and secure title to land. Nelson (2003) explains that through this legislation, extralegals would have a greater incentive to invest in their lands, and a land market would form through the voluntary purchase and sale of the distributed lands. Nelson's report states that by 199137,171 titles to land were granted, equal to 319,311 hectares of land. Although the goals of the Land Titling Project were to increase tenure security and promote a land market, it in fact failed to achieve those goals. When areas where the project was implemented were compared with those where it was not, it was found that the Land Titling Project did not increase tenure security and that there was no significant difference in land market activity. This was a result of a false sense of security these residents had in their ownership prior to the project (Nelson, 2003). Therefore, upon receiving legal ownership through the Land Titling Project, these residents did not subsequently register their property in the national land registry, creating "less than fully legal land titles" (Nelson, 2003).

Although private property ownership is viewed as the preeminent type of property ownership regime, the previous example of an attempt to increase security in property ownership and generation of a land market exemplifies the obstacles which must be systematically overcome in order to ensure successful integration of landless residents and their properties into the land market. The private property rights regime can only be successful in managing tropical forest resources provided adequate enforcement of owners' rights is in place as well ((Nelson (2003), and Andersen and Leal (2001)).

\section{Conflicts and Controversies}

An argument for private property rights stated earlier, provided by De Soto (2000), stressed the need for formal property rights in developing areas such as Honduras. De 
Soto explained the extensive extralegal sector and lack of formal private property rights as a bell jar. Most people living in developing countries are described as living "outside the bell jar" where property is used and protected by extralegal arrangements rooted in informal consensus. Another point put forth by De Soto (2000) was the difficulty of those living in developing countries to "enter the bell jar." The inability to enter the bell jar is attributed to the difficulty associated with accessing legal forms of property and therefore financial gain (De Soto, 2000). The argument put forth here is that there is no simple method for instilling a new property regime to include the extra-legals into the legal sector of property ownership.

Nelson (2003) outlines the obstacles in place in attempting to increase security in property ownership and generation of a land market. One of Nelson's (2003) arguments is that extra-legals feel secure in their informal property ownership, and therefore, implementation of a formal system "undermines" this security, ultimately resulting in land titles that are "less than fully legal." Nelson (2003) further explains that these residents fail to register their newly legal land titles in the land registry system, weakening the process of transferring formal property rights to the informal sector.

Although this paper argues for private property rights, Ostrom (1990) and Quiggin (1993) make arguments for common property rights. Ostrom (1990) argues that common property rights are most successful in small, stable communities. Quiggin (1993) supports this statement by arguing that common property rights allow economies of scale to be used by small communities of land owners. Quiggin (1993) justifies this by stating economies of scale ensure efficiency in allocating resources as the relative costs associated with doing so are kept lower than those that would arise under private property rights regimes, where individuals are acting as "separate firms". It was also suggested that when small communities are able to unite to attain a common goal, resources are ensured for future use by the community. However, this ability deteriorates as exterior forces impact the community, resulting in degradation of the common property rights regime to one of open access (Ostrom, 1990). Ostrom (1990) explains that under open access, degradation of a common resource occurs rapidly, resulting in depletion of the resource, thereby making it unavailable for future generations. In the Honduras case study, the exterior forces consist of population growth and increasing demand for land and forest resources (Tucker, 1999). As Ostrom (1990) and Quiggin (1993) point out, communal rights are most successful in small, stable communities. With population growth as an emerging pressure, Honduras is in fact moving away from small communities. According to Tucker (1999) these forces appear to be driving communal forests into de facto private forests (extra-legal) and agricultural fields.

\section{Free Market Environmentalism Pertaining to Tropical Deforestation}

The Honduras case study utilized in this paper shows that privately owned forests can have lower rates of deforestation than that of publicly owned forests (Godoy et al., 1997). The strongest argument that FME advocates for is that private ownership of natural resources would lead to an efficient allocation and sustainable maintenance of natural resources (Anderson and Leal, 2001). FME assures that private ownership would attribute to owners maintaining their property for future use and long term benefits much more effectively than government agencies, as pointed out by Adler (2000) in his introduction to Ecology, Liberty, and Property: A Free Market Environmental Reader. Activities in Honduras, explained by Nelson (2003), showed that full legal ownership of property even gives owners the opportunity to improve their land and increase yields from existing deforestation, reducing the need for further land clearing. The FME perspective would promote full ownership rights of property, as that creates incentive to maintain owned land (Anderson and Leal, 2001). FME advocates such as Anderson and Leal (2001) believe in a strong rule of law that the Land Titling Project in Honduras attempted to incorporate (an attempt to initiate enforceable property rights throughout the country).

FME promotes the use of market based price systems as laid out by Wagner (1998, pg 321-324), which could be utilized to determine the value of tropical forests. Wagner (1998) shows that market pricing can place accurate value on environmental goods, which serves as guides for economic knowledge. It has been acknowledged by Anglesen (1995) that tropical forests contain value outside of timber production. However, Anglesen does not describe the values that are yet to be determined due to a lack of property structures. Free market environmentalists recognize the underlying inherent need for these property rights and would endorse a system of enforceable rights (Anderson and Leal, 2001). This leads to the creation of a market-based system, presenting a true understanding of the value of tropical forests. With knowledge of the true value of tropical forests comes the ability to conserve and prevent deforestation as needed, through the rights of the owners.

For the reasons previously mentioned, the perspective of FME fits well into the issue of tropical deforestation, while providing an unparalleled solution. The application of FME in countries with tropical deforestation could lead to the establishment of secure property rights, and consequently a reduction in deforestation rates. 


\section{Conclusion}

Issues related to property rights, or lack thereof, were discussed in this report in order to identify failures in preserving tropical forests. It was argued that the implementation of clearly defined and secure property rights regimes could potentially reduce deforestation activity in tropical areas. Trends in tropical deforestation are presented in addition to the examination of four types of property rights regarding forest management, which include: state property, common property, private property, and open-access. Each type was explained in relation to their transferability, exclusivity and degree to which they are enforced, along with their pertinence to tropical forests. The most effective of these four property rights regimes, pertaining to the case study of deforestation in Honduras, was found to be the private property regime. According to Wong (2004), under this regime, an individual who owns land has the right to exclude other users from the land, and regulate the use of resources. Moreover, Nelson (2003) suggests that allowing legal ownership of the land allows landowners to gain access to loans to improve land conditions and prevent further environmental deterioration. Nelson (2003) further implies that this would increase yields from the existing deforested areas, reducing the area needed to support households, ultimately reducing the amount of deforestation in the area. It is important to note however that this type of property rights regime requires adequate enforcement in order to succeed (Nelson, 2003).

It has been demonstrated that a government command and control approach (state) tends be an inefficient way in managing natural forest resources. Furthermore, Wong (2004) and Bromley (2003) state that this approach tends to create avenues for open access properties to develop, due to the lack of effective management and enforcement. Under private ownership, land can be transferred in the market system, and incentives for efficient and sustainable land and resource use will be generated.

A private property regime is recommended in order to reduce tropical deforestation in Honduras and other Tropical areas. Therefore, further analysis should be conducted on the development of a method for efficient and effective establishment of this property rights regime. Each country experiencing tropical deforestation is unique and requires sufficient analysis of these unique traits for the applicable development of property rights. As a case study on Honduras was established, so too should a study of other tropical countries be conducted for the institution of private property rights with their unique situations.

The Free Market Environmentalist perspective was explained in its relation to tropical forests and how this perspective could help incorporate private property rights. It was also identified that with a private ownership regime and adequate enforcement, tropical deforestation could be reduced. With further analysis and the Free-Market Environmentalism perspective, adequate property rights have the potential to stem the tide of tropical deforestation.

\section{References}

Adler, J. (2000) Ecology, Liberty, and Property: A Free Market Environmental Reader. Competitive Enterprise Institute.

Amacher, G., E. Koskela and M. Ollikainen. (2009) Deforestation and Land use Under Insecure Property Rights. Environment and Development Economics, 14(3): 281-303.

Anderson, T. \& D. Leal. (2001). Free Market Environmentalism. Revised Edition, New York, NY: Palgrave.

Angelsen, A. (1995) Shifting Cultivation and Deforestation: A Study from Indonesia. World Development, 23(10): 1713-1729.

Araujo, C., C. Araujo Bonjean, J. Combes, P. Motel and E. Reis. (2009) Property Rights and Deforestation in The Brazilian Amazon. Ecological economics, 68(8-9): 2461 -2468 .

Araujo C, C. Araujo Bonjean, J-L. Combes, P. Motel, \& E Reis. (2010) Does Land Tenure Insecurity Drive Deforestation in the Brazilian Amazon? CERDI, Etudes et Documents, E2010: 13-37.

Aridas, T., Pasquali, V. (2013) The Worlds Richest and Poorest Countries. Global Finance Magazine, 2015.

Barbier, E., J. Burgess and A. Markandya. (1991). The Economics of Tropical Deforestation. Environmental Economics, 20(2): 55-58.

Berkes, F. (1996). Social systems, ecological systems, and property rights. Washington D.C: Island press.

Brandão, A., and C. Souza. (2006) Deforestation in Land Reform Settlements in The Amazon. Imazon, 7,1-4.

Bromley, D. (1998) Determinants of cooperation and management of local common property resources: Discussion. American Journal of Agriculture Economics, 80(3): 665-668.

Cairns, A. (2007) Regulating Ontario's freshwater resources: A free market environmentalist perspective. Studies by Undergraduate Researchers at Guelph, 1(1): 29-39.

Camill, P. (1999) The Deforestation of The Amazon: A Case Study in Understanding Ecosystems and Their Value. Northfield: Carlton College.

Carr, D. (2004) Proximate Population Factors and Deforestation in Tropical Agriculture Frontiers. Population and Environment, 25(6): 585-612. 
Deacon, T. (2012). Institutions, the Resource Curse and the Collapse Hypothesis. Santa Barbara: Property and Environmental Research Center.

De Alessi, M. (2002) Sustainable Development and Marine Fisheries. Sustainable Development Promoting Progress or Perpetuating Provert? London: Profile Books.

The World Bank (2003) Land Policies for Growth and Poverty Reduction. Berlin. Oxford University Press 2003.

De Soto, H. (2000) The Mystery of capital: Why Capitalism Triumphs in the West and Fails Everywhere Else. New York, NY: Basic Books.

Ekbäck, P. (2009) Private, Common, and Open Access Property Rights in Land: An Investigation of Economic Principles and Legislation. Nordic Journal of Surveying and Real Estate research, 6(2)57-74.

Food and Agriculture Organization. (2010) Global Forest Resources Assessment 2010: Main Report, Rome:FAO.

Food and Agriculture Organization. (2005) Global Forest Resources Assessment 2010: Main Report, Rome:FAO.

Godoy, R., K. O'Neill, S. Groff, P. Kostishack, A. Cubas, J. Demmer, K. Mcsweeney and J. Overman. (1997) "Household Determinants of Deforestation Amerindians in Honduras" World Development , 25 (6): 977-987.

Hill, P., \& R. Meiner. (1998) Who owns the Environment: The Constitutional Protection of Private Property. Lanham: Rowman \& Littlefield Publishers.

Hyde, W., G. Amacher and W. Magrath. (1996) "Deforestation and Forest Land Use: Theory, Evidence, and Policy Implications" Oxford Journals, 11(2): 223 248.

International Monetary Fund. (2012) World Economic Outlook: Growth Resuming, Dangers Remain. Washington, DC: International Monetary Fund.

Lambin, E., H. Geist, \& E. Lepers, (2003). Dynamics of Land-Use and Land-Cover change in tropical regions. Annual Review of Environment and Resources, 28: 205241.

Mendelsohn, R. (1994) Property Rights and Tropical Deforestation. Oxford Economic, 46: 750-756.

Merlo, M. (1995). Common property forest management in northern Italy; a historical and socio-economic profile. Unasylva, 46(180): 58-63.

Millikan, B. (1992) Tropical Deforestation, Land Degradation, and Society: Lessons from Rondonia, Brazil. Latin American Perspectives, 19(1): 45-72.
Nanjundaiah, C. (2008) Do Property Rights Really Influence Forest Conservation and Management in Western Ghats of India, New Delhi, India: Manak Publication Private Ltd.

Nelson, R. (2003) Honduras Country Brief: Property Rights and Land Markets, Wisconsin: Development Alternatives Inc.

Ostrom, E. (1990) Governing the Commons: The Evolution of Institutions for Collective. Cambridge , UK: Cambridge University Press

Quiggin, J. (1993) Common Property, Equality and Development. World Development 21(7): 1123-1138.

Sandler, T. (1993) Tropical Deforestation: Markets and Market Failures. Land Economics, 69(3): 225-233.

Southgate, D. (2002) Forest Conservation and Development: the Role if Institutions" Sustainable Development: Promoting Progress or Perpetuating Poverty? London: Profile Books.

Southworth, J., and C. Tucker. (2001) The Influence of Accessibility, Local Institutions, and Socioeconomic Factors on Forest Cover Change in the Mountains of Western Honduras. Mountain Research and Development, 21 (3): 276-283.

Thomas, A. (2011) Killing Two Birds with One Stone: Implementing Land Reform and Combating Climate Change in Brazil's Amazon Under Law 11.952.09. Seattle Journal For Social Justice, 9(2): 1107-1155.

Tietenberg, T. and L. Lewis. (2009) Environmental and Natural Resources Economics, Boston, MA: Pearson Education Inc.

Tucker, C. (1999) Private Versus Common Property Forests: Forest Conditions and Tenure in a Honduran Community. Human Ecology, 27(2): 201-230.

United Nations Development Programme. (2011) Human Development Report 2011, New York: Palgrave Macmillan.

Wong, B. (2004). Common Pool Resources Management: Are Common Property Rights a Good Alternative to External Regimes? Virginia: College of Architecture and Urban Studies. 
